\title{
THE CYTOLOGICAL LOCALIZATION OF ACTH IN THE HUMAN PITUITARY*
}

\author{
By A. LEZNOFF, $\dagger$ J. FISHMAN, M. TALBOT, E. E. McGARRY, J. C. BECK AND \\ B. ROSE \\ (From the McGill University Clinic, Royal Victoria Hospital, Montreal)
}

(Submitted for publication February 15, 1962; accepted May 3, 1962)

Among the methods for demonstrating the cellular sites of production of anterior pituitary hormones are special histochemical techniques correlated with clinical and experimental findings (1-3), ultracentrifugation studies $(4,5)$, tissue culture methods (6), and fluorescent antibody methods (7-9). The fluorescent antibody technique has the distinct advantages of specificity and of being applicable to pituitaries in histologic section. The success of this method depends upon the availability of highly purified hormones which can be used as antigens and, indeed, its successful application attests to the purity of such hormones.

The cellular site of human growth hormone in human pituitary glands has previously been demonstrated (9). The present report concerns the localization of ACTH in human pituitaries.

\section{METHODS AND MATERIALS}

Highly purified porcine and human ACTH ${ }^{1}$ were emulsified in complete Freund's adjuvant ${ }^{2}$ and injected into the foot pads of rabbits at 2 -week intervals. Animals were bled when hemagglutinating antibody titers (10) of $1: 3000$ to $1: 5000$ were obtained on test bleedings.

The antisera were tested by hemagglutination inhibition against other pituitary hormone preparations for species and hormone specificity $(11,12)$. Cross reactions occurred only with preparations known by biological assay to contain ACTH in amounts which roughly correlated with the degree of cross-reaction demonstrated (12). By using antisera to porcine ACTH, comparable amounts of the original antigen, of pure ACTH supplied by Dr. C. H. Li, of human ACTH, and of the beta fraction of Bell inhibited the reaction, while the other Bell fractions showed a weak cross-reaction, as did melanocyte-stimulating hormone (MSH) (Table I). The anti-

* Supported by a grant in aid, Medical Research Council of Canada and Grant E1322(C2), U. S. Public Health Service.

† Present address: Jewish General Hospital, Montreal.

1 Porcine and human ACTH supplied through the courtesy of Nordic Biochemicals, Montreal.

2 Obtained commercially through Difco. sera to porcine ACTH specifically inhibited the ACTHstimulated release of free fatty acids from the rat epididymal fat pad in vitro (12). No precipitation occurred between ACTH and anti-ACTH sera on ring test or in gel, when a modification of the method of Preer was used.

Fluorescein isothiocyanate was conjugated to antiporcine-ACTH rabbit $\gamma$ globulin and antihuman-ACTH rabbit $\gamma$ globulin by the method of Marshall, Eveland and Smith (13). The conjugates were absorbed with mouse liver powder prior to use (14), and where the layer technique (15) was employed, the unlabeled antiserum was absorbed with human liver powder.

Nine pituitaries used for specificity studies were obtained at surgery or at autopsy less than 2 hours post mortem. They were frozen in liquid nitrogen and stored at $-20^{\circ}$. C. Five- to six $-\mu$ sections were cut in a cryostat and "fixed" in 95 per cent ethanol or reagent acetone at $37^{\circ} \mathrm{C}$ for 30 minutes. They were then washed in saline. Staining procedure for the direct method was done according to Vazquez and Dixon (16) and for the layer technique, according to Weller and Coons (15).

The following sections of human pituitaries were made. When possible, pars anterior and pars posterior were included in the section. a) Stained, by the direct method,

TABLE I

Cross-reaction of various ACTH preparations with antibodies to porcine ACTH; hemagglutination inhibition used

\begin{tabular}{cc}
\hline Preparation & $\begin{array}{c}\text { Inhibition } \\
\text { factor } *\end{array}$ \\
\hline Porcine ACTH & 1 \\
Human ACTH & 1 \\
ACTH (Li) & 1 \\
ACTH fractions & \\
$\alpha_{1} \alpha_{2}$ & 100 \\
$\beta$ & 4 \\
$\gamma_{1} \gamma_{2}$ & 100 \\
$\delta_{1}$ & 100 \\
Human MSH & 313
\end{tabular}

* The smallest amount of porcine ACTH required to inhibit the reaction between porcine ACTH-sensitized red cells and antiporcine-ACTH is used as the standard of comparison in each experiment and given a value of 1 . The inhibition factor represents the relative amount, by weight, of other preparations required to produce inhibition of the reaction. Each factor represents at least 3 experiments done in duplicate. 
with fluorescein-labeled antiporcine or antihuman-ACTH; b) treated, by layer technique, with unlabeled antiporcine$\mathrm{ACTH}$ followed by fluorescein-labeled chicken antirabbit $\gamma$ globulin; $c$ ) unstained; $d$ ) stained directly with labeled normal rabbit $\gamma$ globulin or labeled antirabbit $\gamma$ globulin; $e)$ stained directly with labeled antiporcine-ACTH which had been absorbed in the test tube with excess ACTH; f) treated with unlabeled anti-ACTH for 45 minutes followed by labeled anti-ACTH for 15 minutes; $g$ ) treated with unlabeled normal rabbit serum for 45 minutes followed by labeled anti-ACTH for 15 minutes; and $h$ ) treated with normal rabbit serum followed by fluorescent anti-rabbit $\gamma$ globulin.

Procedures $c, d, e, f$ and $g$ together, and $h$ constitute the staining specificity controls.

Frozen sections of thyroid, parathyroid, liver, and kidney were stained by the direct method $a$ and the layer technique $b$ as tissue controls. Studies were also done on 15 formalin-fixed, paraffin-embedded, normal human pituitaries and pituitary adenomata from four patients with acromegaly, four patients with no detectable endocrine disturbance, and one patient with Cushing's disease. The same specificity controls were employed. These sections were cut and mounted in mirror-image pairs, so that the uppermost surface of each section was the adjacent aspect of the same interface, thus allowing cell-for-cell comparison of the two slides (9). One section was stained as by $a$ and $b$ above and the adjacent section was stained by the aldehyde fuchsin technique (17) with woodstain scarlet and light green as a counterstain. The pairs were studied together, one with the fluorescence microscope, the other with a conventional microscope. Photomicrographs were made of identical mirror-image fields. Those of the fluorescent sections were printed from the reverse side of the transparency, so that resultant prints were superimposable (9).

\section{RESULTS}

Fluorescent staining of human pituitary cells was achieved with fluorescein-labeled antiporcine$\mathrm{ACTH}$ and antihuman-ACTH. The fluorescent staining was brighter with antiporcine-ACTH, which was the higher titered antiserum, and all subsequent studies were therefore performed with this fluor. Furthermore, it was felt that the use of antiporcine-ACTH would reduce the possibility of nonspecific fluorescent localization in human pituitaries.

All frozen sections of human pituitaries treated with fluorescent anti-ACTH showed specific staining of cells and groups of cells in the pars anterior (Figure 1), and scattered sparsely throughout the pars posterior, when included in the section, there were occasional groups of two to five fluorescent cells around a small blood vessel (Figures 2,
3). In some of these sections there was a band of fluorescent cells in the zone of basophilic infiltration in the margin of the pars posterior (Figure 4$)$. The staining of cells in the region between the pars anterior and the pars posterior was not consistent. In some pituitaries these cells stained very brightly, showing much granularity (Figure 5); in others, only scattered groups of cells fluoresced.

Staining of sections from formalin-fixed, paraffin-embedded blocks with fluorescent antiporcineACTH was inconsistent. Some pituitaries stained as well as the frozen sections; some stained more faintly; some did not stain (Figure 6). The brightest staining in formalin-paraffin or frozen sections was achieved by the layer technique.

Controls were performed in all experiments. In the paired inhibition controls ( $f$ and $g$ ), intensity of staining was much less in slides "inhibited" with unlabeled anti-ACTH than in those treated with normal rabbit serum. As our antiACTH is a nonprecipitating antibody, absorption with ACTH could not be complete. Slides stained with fluorescent anti-ACTH which had been absorbed with excess ACTH showed cells with very faint or no fluorescent staining (Figures 7,8 ). When the layer technique was used, there was no staining when nonfluorescent normal rabbit serum was the first layer, and staining was much reduced or absent when "absorbed" anti-ACTH was used. Sections of pituitary left unstained, those treated with nonspecific fluors, or sections of other tissues treated with fluorescent anti-ACTH did not stain.

When mirror-image pairs of formalin-fixed sections were studied (Figures 9, 10), it could be seen that the cells that fluoresced were basophils, but that the intensity of basophilic granularity did not correlate with the brilliance of fluorescent staining. In most instances fluorescent cells corresponded to dark blue basophils, but in some cases the fluorescent cells were pale blue, sparsely granulated basophils and, in a few cases, purple basophils. Not all basophils corresponded to fluorescent cells. More than half did not show fluorescence in the corresponding slide.

The pituitary adenoma from the patient with Cushing's disease was studied with routine and special stains, but the adenoma could not be classified pathologically; it appeared as a relatively anaplastic chromophobe adenoma in which very 
few cells contained scanty basophil granules. At the border there was a rim of compressed normal pituitary tissue in which the cells were mainly eosinophils.

When the section was stained with fluorescent antihuman growth hormone (9), these eosinophils fluoresced, but the adenoma cells did not. When treated with fluorescent anti-ACTH, the adenoma cells fluoresced but not the normal eosinophil cells (Figures 11-14). The other pituitary adenomata studied did not stain with fluorescent anti-ACTH.

\section{DISCUSSION}

When the specificity of antisera can be demonstrated by immunochemical, biological, and immunohistological controls, specific staining in a tissue with the fluorescent antibody technique is presumptive evidence of the presence of the antigen. Staining by histochemical methods is de-

Fig. 1. Frozen Section of NORMal human PItUiTARY, PARS ANTERIOR, "STAINED” WITH FLUORESCENT ANTIPORCINE-ACTH. Acinus surrounded by cells which show fluorescence in the cytoplasm but not in the nucleus $(200 \times)$.

Fig. 2. Formalin-PARAFFin SECtion OF NORMAL HUMAN PITUITARY, PARS POSTERIOR, STAINED WITH FLUORESCENT ANTI-ACTH. Group of fluorescent cells around small blood vessel $(400 \times)$. This print was made from the reverse side of the transparency. The fluorescent cells are the same as those in Figure 3.

Fig. 3. Identical field (slightly rotated) as FigURE 2, STAINED BY THE ALDEHYDE FUCHSIN TECH NIQUE. The upper surface of this section is the opposite aspect of the same interface as Figure 2. This print was made from the "correct" side of the transparency $(400 \times)$. For aldehyde fuchsin stain, see text.

Fig. 4. Formalin-PARAFFin SECtion OF NORMAL HUMAN PITUITARY SHOWING THE JUNCTION OF THE PARS ANTERIOR AND THE PARS POSTERIOR STAINED WITH FLUORESCENT ANTI-ACTH. A band of fluorescent cells extends into the pars posterior. In this field the subjacent pars anterior contains few fluorescent cells $(100 \times)$.

Fig. 5. Frozen SECTION OF NORMAL hUMAN PITUITARY, CYSTIC REGION BETWEEN PARS ANTERIOR AND PARS POSTERIOR STAINED WITH FLUORESCENT ANTI-ACTH. Note fluorescent cells with distinct granules $(400 \times)$.

Fig. 6. Formalin-PARAFFin SECTION OF NORMAL HUMAN PITUITARY, PARS ANTERIOR, STAINED WITH FLUORESCENT ANTI-ACTH. Note distinct fluorescence of many cells $(100 \times)$.

Fig. 7. Formalin-PARAFFin SECTION OF NORMAL HUMAN PITUITARY SHOWING THE JUNCTION OF THE PARS ANTERIOR AND THE PARS POSTERIOR. Same specimen as Figure 4, stained with fluorescent anti-ACTH which had pendent upon chemical characteristics (e.g., 1 to 2 glycol groups), which may be shared by more than one constituent of a cell. With a variety of techniques, many attempts have been made to correlate histochemical characteristics of human pituitaries with clinical endocrinopathies and, by deduction, to associate certain cells in the pituitary with secretion or storage of individual hormones. There is no good agreement among authors with regard to the cellular site of ACTH or the classification of basophils. It is not the purpose of this paper to become involved in a discussion of the merits of the various nomenclatures but rather to show that by using the fluorescent antibody technique, a specific antiserum to ACTH is localized in cells that stain as basophils when techniques routinely applied to pituitary tissue are used.

The studies presented here demonstrate directly that ACTH is located in basophil cells in

been absorbed with ACTH. Note absence of specific staining $(100 \times)$.

Fig. 8. Formalin-PARAfFin SECtion OF NORMAL HUman pituitary, pars anterior. Same specimen as Figure 6, stained with fluorescent anti-ACTH which had been absorbed with ACTH. Note absence of specific staining $(100 \times)$.

Fig. 9. Formalin-PARAFFin SECtion of NORMAL HUMAN PITUitaRy STAINED With FLUORESCENT ANTI-ACTH. This section is the mirror-image of Figure 10, but the print was made from the reverse side of the transparency to render it superimposable. Note " $\mathrm{V}$ " of fluorescent cells $(400 \times)$.

Fig. 10. Adjacent section to Figure 9 aldehyde FUCHSIN STAIN. Basophil cells which differ in color and granularity are the same cells as those which fluoresce in Figure 9. Some basophils and all other cells correspond to cells which do not fluoresce in Figure $9(400 \times)$.

Fig. 11. Formalin-Paraffin Section of pituitary Adenoma From a patient with Cushing's disease. Border between adenoma cells, left, and "normal" eosinophil cells, right. Aldehyde fuchsin stain, see text $(200 \times)$.

Fig. 12. Formalin-Paraffin Section, SAME adenoma as Figure 11, Similar field, Stained with fluoresCENT ANTI-ACTH. Adenoma cells at the bottom are fluorescent; normal pituitary cells are not $(200 \times)$.

Fig. 13. Formalin-Paraffin Section, SAME Adenoma as Figure 11, Similar field, Stained With fluoresCENT Antihuman GROWth hORMONe. Adenoma tissue is to the left of center. Note bright fluorescence in compressed normal pituitary $(100 \times)$.

Fig. 14. Formalin-Paraffin SeCtion, SAME Adenoma as Figure 11, SHOWING THE CENTER OF ADENOMA STAINed WITH FLUORESCENT ANTI-ACTH $(400 \times)$. 


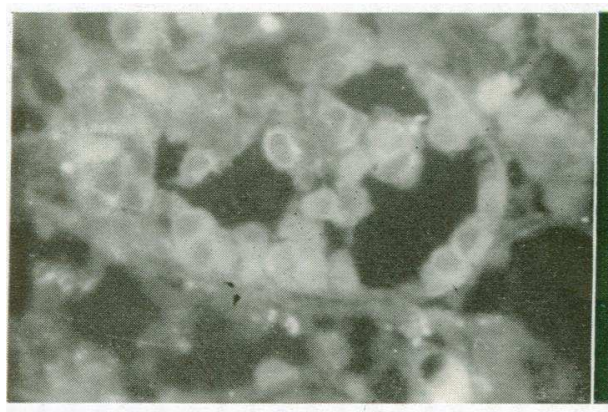

1

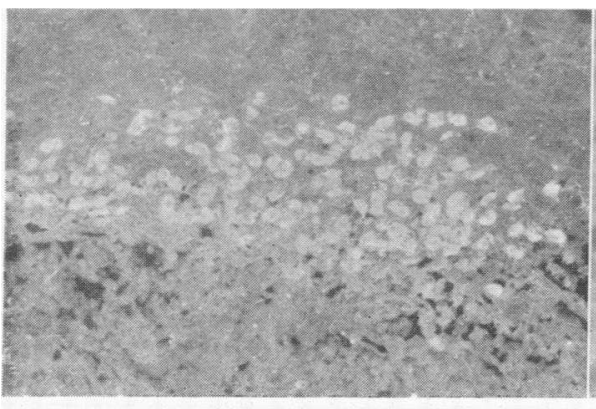

4
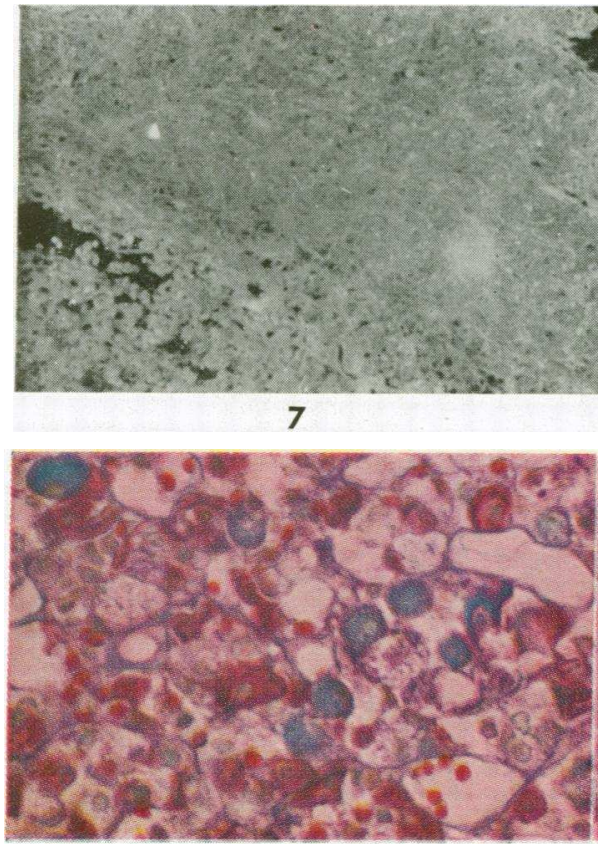

10

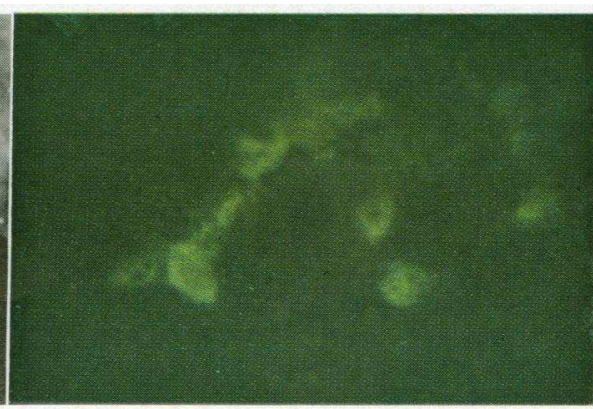

2

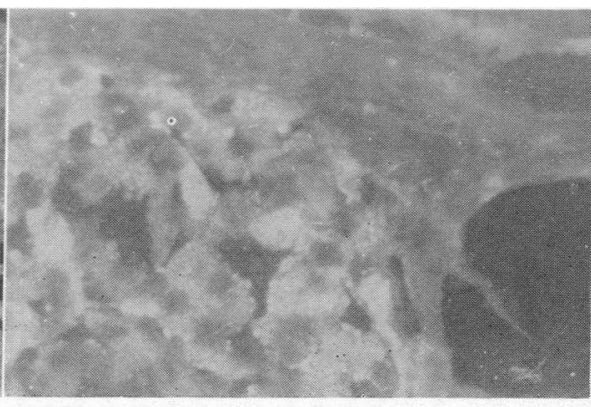

5

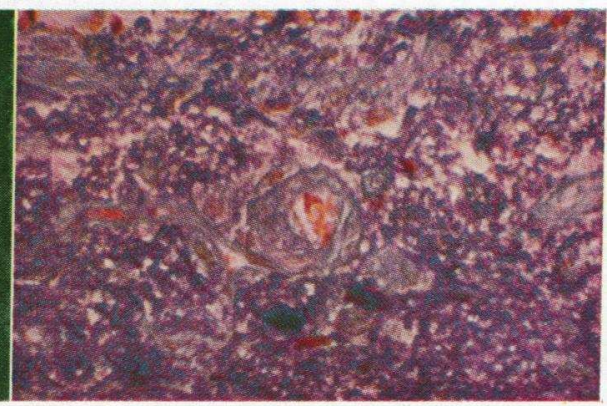

3

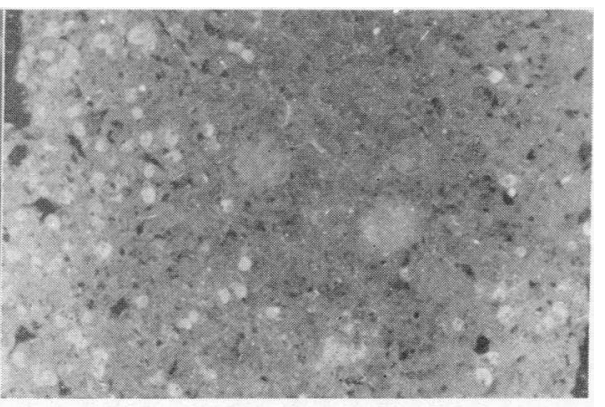

6

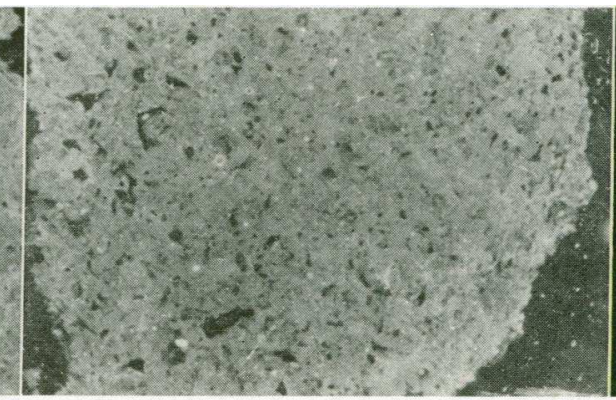

8

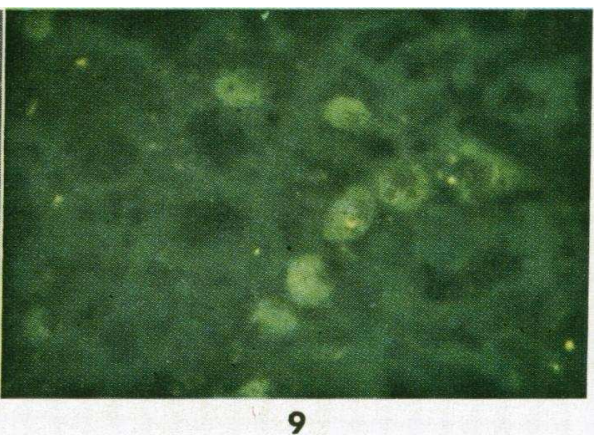

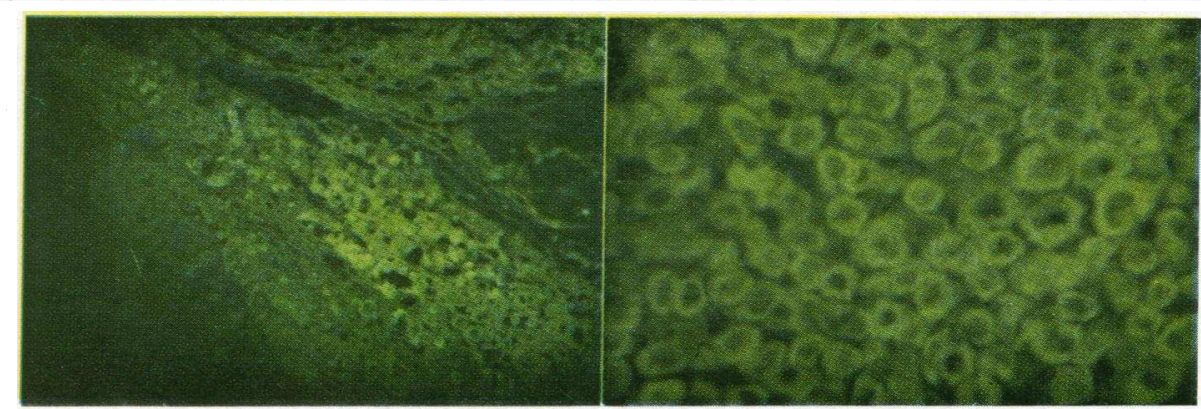


the human pituitary, that cells containing ACTH may be densely or sparsely granulated, and that minor variations in the color of the basophilsi.e., light or darker blue, or purple by Gomori's method (17)-may not be a function of the hormone present in the cells.

When pituitaries obtained later than 2 hours post mortem were studied, distinct localization of ACTH was not obtained but, rather, the sections stained with fluorescent anti-ACTH showed cells with poorly defined boundaries with fluorescence seeming to diffuse out of the cells into the interstitium. We believe this indicates ACTH leakage. With other methods (1-3) the freshness of the pituitary was probably not so critical, since no mention is made of this phenomenon.

It is quite possible that ACTH may exist in two different forms (as well as in different quantities) in pituitary cells. In ultracentrifugation studies, Brown, LaBella and Ulvedal $(4,5)$ showed that ACTH was found in the microsomal fraction and in the supernatant, but not in the acidophilic granular fraction. The work of Currie and Davies, who used extraction methods, also suggests that $\mathrm{ACTH}$ is found in the pituitary in two forms (18).

Using extraction and bioassay methods, Morris, Russell, Landgrebe and Mitchell (19) suggested that the cells in the zone of basophilic infiltration in the posterior pituitary contain "intermedin" (or melanocyte-stimulating hormone, $\mathrm{MSH}$ ). The present studies demonstrate the presence of ACTH in many of the basophil cells in the pars posterior. Although these cells could contain $\mathrm{MSH}$ as well as ACTH, the degree of cross reactivity between MSH and anti-ACTH serum cannot account for the fluorescent staining seen. In hemagglutination studies, $50 \mu \mathrm{g}$ of $\mathrm{MSH}$ was required to give the same inhibition as that obtained with $0.16 \mu \mathrm{g}$ of $\mathrm{ACTH}$. This represents a factor of over 300 by weight or a factor of 450 on a molar basis. Since dilution by a factor of 2 of the fluorescent antiserum resulted in marked diminution of fluorescent staining, localization of MSH is well beyond the limits of sensitivity of this antiserum.

Though the value of the method presented here is mainly investigative, it may have clinical application as in the identification of hormones in the cells of pituitary tumors.

\section{SUM M ARY}

When adequately controlled, the fluorescent antibody technique can be used to identify the cellular site of ACTH in the human pituitary.

ACTH is present in basophil cells in the pars anterior and the pars posterior.

The intensity of fluorescent staining does not correlate well with the degree of basophilic granularity or minor variations in the staining characteristics of the basophil cells.

\section{ACKNOWLEDGMENTS}

The authors wish to acknowledge the generous aid of the following firms in helping to defray the cost of publication for the plates in this manuscript: of Montreal, Ayerst, McKenna and Harrison Ltd.; Ciba Company Ltd.; Geigy Pharmaceuticals, Division of Geigy (Canada) Limited; Hoffman-LaRoche Ltd.; Frank W. Horner Ltd.; Sandoz Pharmaceuticals, Division of Sandoz (Canada) Ltd.; Schering Corporation Ltd.; and Smith Kline and French Inter-American Corporation; and of Toronto, The Upjohn Company of Canada.

\section{REFERENCES}

1. Ezrin, C., Swanson, H. E., Humphrey, J. G., Dawson, J. W., and Hill, F. M. Beta and delta cells of the human adenohypophysis: their response to adrenocortical disorders. J. clin. Endocr. 1959, 19, 621.

2. Halmi, N. S. Two types of basophils in the anterior pituitary of the rat and their respective cytophysiological significance. Endocrinology 1950, 47, 289.

3. Adams, C. W. M., and Pearse, A. G. E. Classification of the mucoid (basophil) cells in the normal and pathological human adenohypophysis. J. Endocr. 1959, 18, 147.

4. Brown, J. H. U., LaBella, F. S., and Ulvedal, F. Studies on the intracellular localization of anterior pituitary hormones by means of differential centrifugation. Endocrinology 1960, 66, 1.

5. Brown, J. H. U., and Ulvedal, F. Studies on ultracentrifuge fractions of anterior pituitary with special reference to adrenocorticotrophic hormone. Endocrinology 1960, 66, 175.

6. Thompson, K. W., Vincent, M. M., Jensen, F. C., Price, R. T., and Schapiro, E. Production of hormones by human anterior pituitary cells in serial culture. Proc. Soc. exp. Biol. (N. Y.) 1959, 102, 403.

7. Marshall, J. M., Jr. Localiation of adrenocorticotropic hormone by histochemical and immunochemical methods. J. exp. Med. 1951, 94, 21.

8. Cruickshank, B., and Currie, A. R. Localization of tissue antigens with the fluorescent antibody tech- 
nique: application to human anterior pituitary hormones. Immunology 1958, 1, 13.

9. Leznoff, A., Fishman, J., Goodfriend, L., McGarry, E., Beck, J., and Rose, B. Localization of fluorescent antibodies to human growth hormone in human anterior pituitary glands. Proc. Soc. exp. Biol. (N. Y.) 1960, 104, 232.

10. Gordon, J., Rose, B., and Sehon, A. H. Detection of "non-precipitating" antibodies in sera of individuals allergic to ragweed pollen by an in vitro method. J. exp. Med. 1958, 108, 37.

11. Fishman, J., McGarry, E. E., and Beck, J. C. Studies using anterior pituitary hormones as antigens. Proc. Soc. exp. Biol. (N. Y.) 1959, 102, 446.

12. McGarry, E. E., Ballantyne, A., and Beck, J. C. Detection and assay of hormones by immunochemical means. Ciba Found. Coll. Endocr. In press.

13. Marshall, J. D., Eveland, W. C., and Smith, C. W. Superiority of fluorescein isothiocyanate (Riggs) for fluorescent-antibody technic with modification of its application. Proc. Soc. exp. Biol. (N. Y.) 1958, 98, 898.
14. Coons, A. H., Leduc, E. H., and Connolly, J. M. Studies on antibody production. I. A method for the histochemical demonstration of specific antibody and its application to a study of the hyperimmune rabbit. J. exp. Med. 1955, $102,49$.

15. Weller, T. H., and Coons, A. H. Fluorescent antibody studies with agents of varicella and herpes zoster propagated in vitro. Proc. Soc. exp. Biol. (N. Y.) 1954, 86, 789.

16. Vazquez, J. J., and Dixon, F. J. Immunohistochemical analysis of amyloid by the fluorescence technique. J. exp. Med. 1956, 104, 727.

17. Gomori, G. Aldehydre-fuchsin: A new stain for elastic tissue. Amer. J. clin. Path. 1950, 20, 665.

18. Currie, A. R., and Davies, B. M. A. in Human Adrenal Cortex, A. R. Currie, J. K. Grant, T. Symington, Eds. Edinburgh, Livingstone, 1962, p. 248.

19. Morris, C. J. O. R., Russell, D. S., Landgrebe, F. W., and Mitchell, G. M. The melanophore-expanding and corticotrophic activity of human pituitary tissue. J. Endocr. 1956, 14, 263.

\section{SPECIAL NOTICE TO SUBSCRIBERS}

Post Offices will no longer forward the Journal when you move.

Please notify The Journal of Clinical Investigation, Business Office, 10 Stoughton Street, Boston 18, Mass., at once when you have a change of address, and do not omit the zone number if there is one. 